\title{
DAMPAK POSITIF EKONOMI SEBAGAI HASIL TATA KELOLA DESTINASI YANG BERKELANJUTAN DI DESA KUTUH KAWASAN PANTAI PANDAWA - BALI
}

\author{
Diena Mutiara Lemy \\ Universitas Pelita Harapan \\ Email: diena.lemy@uph.edu \\ Kim Min Jun \\ Universitas Pelita Harapan \\ Email: alswns97105@gmail.com \\ Madeline Stefanie Tjang \\ Universitas Pelita Harapan \\ Email: madelinetjang@ymail.com \\ Wu Lei Lei \\ Universitas Pelita Harapan \\ Email: w11347090500@gmail.com
}

\begin{abstract}
The purpose of this research paper to identify the impact of sustainable tourism management towards the economic conditions of a community. In 2018, Pandawa Beach has won first rank for Indonesia Sustainable Tourism Awards (ISTA) in the field of economic utilization to local communities hence the author decided to use Pandawa Beach for the research. The qualitative data were collected from interviews and the quantitative data were collected from questionnaires. The method for analyzing the data is using descriptive analysis. The research result shows that sustainable tourism gives positive impacts towards the economic conditions on Kutuh Village. 72 people out of 90 are satisfied with the current economic welfare of the local community. The data is also valid because the AVE and CR results are all above 0.7 which means the results are acceptable.
\end{abstract}

Keywords: sustainable tourism management, economic impact of tourism, Pandawa Beach Bali 


\section{Pendahuluan}

Pariwisata adalah salah satu industri paling kuat dan berpengaruh di dunia di mana ia menggunakan tempat-tempat alam, budaya, dan sejarah yang indah di belahan dunia mana pun sebagai sumber daya utamanya. Oleh karena itu, tata kelola yang tepat dan bertanggung jawab adalah hal harus dilakukan. Pariwisata berkelanjutan menyeimbangkan evolusi ekonomi menuju batasan yang diberlakukan oleh kebutuhan masyarakat lokal dan lingkungan. Oleh karena itu, kebutuhan untuk pembangunan pariwisata berkelanjutan menjadi penting (Kostić, 2014).

Bali sebagai salah satu tujuan wisata terpopuler di kepulauan Indonesia, merupakan pulau dan rumah bagi budaya kuno yang dikenal dengan keramahannya yang hangat. Istana dan kuil eksotis dengan latar belakang alam yang menakjubkan yang merupakan bagian dari atraksi utama. Sebagai sebuah destinasi, Bali memiliki daya Tarik yang luar biasa karena alam yang memesona, tradisi yang kaya, budaya yang unik, dan upacara yang penuh warna. Luas pulau Bali adalah 5.780 kilometer persegi berdasarkan situs World Population Review, 2019. Menurut situs The Bali Today pada tahun 2019, jumlah penduduk Bali adalah 4.292.200 jiwa pada tahun 2018.Karena pertumbuhan industri pariwisata tumbuh secara eksponensial, hal ini signifikan bagi Permintaan produk pariwisata Bali tumbuh secara berkelanjutan dan juga sejalan dengan fasilitas yang tersedia. Oleh sebab itu, strategi terkait tata kelola hendaknya tidak hanya berfokus atau memenuhi aspek ekonomi pariwisata tetapi juga dampak sosial dan lingkungannya.

Pantai Pandawa terletak di desa Kutuh yang berada di Kecamatan Kuta Selatan di Kabupaten Badung, Bali. Dahulu sebelum Pantai Pandawa menjadi destinasi terkenal di Bali, pantai ini tersembunyi di balik bukit yang terletak di lembah yang dalam dan dikelilingi oleh tebing batu putih yang membuat aksesibilitas menjadi sulit sehingga Kawasan ini menjadi kosong. Saat itu hanya ada beberapa wisatawan yang 
pernah mengunjungi pantai namun jumlahnya tidak banyak. Peselancar asing atau wisatawan domestik hanya sedikit. Selang beberapa waktu, Pemerintah Kabupaten Badung menyadari bahwa pantai itu sendiri memiliki potensi menarik wisatawan dengan cepat, sehingga kemudian destinasi ini diluncurkan sebagai daya pikat andalan baru. Saat ini, aksesibilitas menuju Pantai Pandawa sangat baik dan nyaman untuk kendaraan apapun.

Sejak dibuka pada 27 Desember 2012, pantai ini dengan cepat menarik cukup banyak wisatawan baik dari dalam maupun luar negeri. Menurut data Kepala Pengelola Pantai Pandawa tahun 2013-2018, jumlah pengunjung dari wisatawan lokal mencapai 355.097 orang dan jumlah pengunjung dari wisatawan mancanegara mencapai 45.943 orang. Pada tahun 2018 pengunjung dari wisatawan mancanegara telah mencapai 275.940 orang dimana terjadi peningkatan sebesar 500\% dari tahun 2013 dan pengunjung nasional yang mencapai 1.706.404 orang dimana terjadi peningkatan sebesar $380 \%$ dari tahun 2013. Peningkatan jumlah pengunjung Pengunjung telah menunjukkan bahwa Pantai Pandawa telah dikenal oleh wisatawan lokal dan mancanegara. Inilah salah satu alasan mengapa Pantai Pandawa berpotensi menarik wisatawan yang berkontribusi dalam menghasilkan devisa negara bagi Indonesia. Namun demikian, hal ini juga menjadi alasan lain mengapa pengelolaan pariwisata di Kawasan ini harus dilakukan dengan cara yang tepat dan bertanggung jawab.

Salah satu bukti bahwa destinasi ini telah dikelola secara berkelanjutan adalah Raihan penghargaan Indonesia Sustainable Tourism Awards (ISTA) 2018 sebagai peraih emas atau peringkat pertama bidang Pemanfaatan Ekonomi untuk Masyarakat Lokal (Ramdhani, 2018). Model pengelolaan pariwisata berkelanjutan yang diterapkan berpedoman pada Desa Adat atau yang dikenal dengan desa adat (Dharmayudha, 2001). Konsep pembangunan desa sendiri berbasis dari bawah ke atas 
yang diatur oleh desa sendiri dan bukan dari atas ke bawah yang diatur oleh kabupaten.

Meski Pantai Pandawa sudah terkenal di kalangan wisatawan nasional maupun mancanegara, dan juga peraih medali emas ISTA tahun 2018, destinasi itu sendiri tetap perlu dikelola secara lebih berkelanjutan dari sebelumnya dengan peningkatan manfaat ekonomi bagi warga setempat. yang mendiami daerah tersebut. Oleh karena itu, penelitian ini akan memilih pantai Pandawa sebagai lokasi penelitian dan bertujuan menjadikan Pantai Pandawa sebagai role model dalam keberhasilan implementasi pariwisata berkelanjutan yang dapat mendongkrak perekonomian. Oleh sebab itu, tulisan ini akan fokus pada bagaimana Kawasan ini dikelola sehingga bisa menjadi destinasi yang unggul, berdaya saing dan memberikan manfaat ekonomi bagi para pemangku kepentingannya.

\section{Teori/Kerangka Berfikir dan Metode}

\section{Teori dan Kerangka Berpikir}

Pantai Pandawa resmi dibuka pada bulan Desember 2012 dan diawali dengan adanya festival pantai (Swabawa, 2018). Potensi utama pantai yang menarik wisatawan untuk berkunjung adalah pemandangannya sendiri dengan pasir yang bersih dengan ombak yang tenang, bebas polusi dan pedagang tempat wisatawan dapat melakukan aktivitas wisata bahari. Tersedia juga warung makan yang menjual nasi goreng, mie goreng, ikan laut bakar dan beberapa makanan western. Kursi berjemur dengan payung juga bisa disewa dari warung makan. Karena semakin berkembangnya Pantai Pandawa, maka semakin banyak pula wisatawan yang berkunjung ke tempat tersebut. 
Pada Februari 2013 hingga Januari 2014, tingkat pengunjung baik wisatawan mancanegara maupun domestik cukup berfluktuasi kecuali pada bulan April, Juli, September, dan Oktober yang mengalami penurunan. Namun secara keseluruhan, tingkat pengunjung meningkat 26,59\% untuk wisatawan domestik dan 34,37\% untuk wisatawan mancanegara. Tarif rata-rata pengunjung bulanan adalah 32.760 orang untuk wisatawan domestik dan 4.603 orang untuk wisatawan asing.

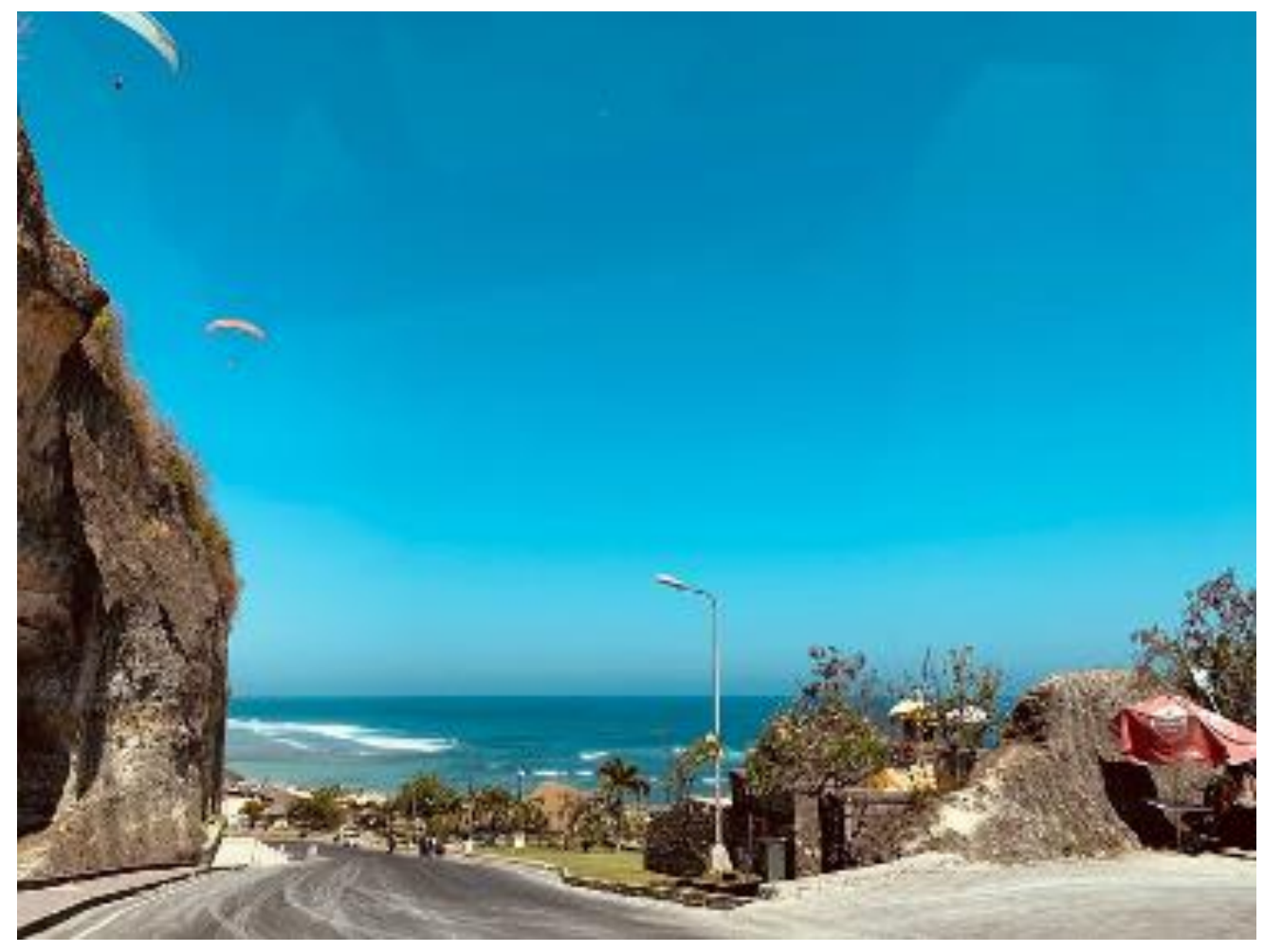

Gambar 1. Akses menuju Kawasan Pantai Pandawa

Sumber: Dokumentasi Peneliti 2019

Kawasan ini telah dikelola dengan menggunakan prinsip pariwisata berkelanjutan berbasis komunitas. Pariwisata berkelanjutan adalah pariwisata yang memperhitungkan sepenuhnya dampak ekonomi, sosial, dan lingkungannya saat ini dan di masa depan, memenuhi kebutuhan pengunjung, industri, lingkungan, dan komunitas tuan rumah (UNWTO, 2005). Dengan kata lain, pariwisata berkelanjutan tidak hanya tentang bagaimana memaksimalkan keuntungan tetapi juga 
memperhatikan secara penuh dampak lingkungan dan sosial dengan tetap menjaga keseimbangan stabilitas ekonomi. Selain itu pariwisata berkelanjutan juga mempertimbangkan kebutuhan pengunjung dan kesejahteraan masyarakat tuan rumah di mana kedua belah pihak merasakan manfaat karena pariwisata. Sesuai dengan uraian di atas, tulisan ini membahas bagaimana tata kelola dengan prinsip yang berkelanjutan dapat memberikan manfaat ekonomi yang sangat signifikan bagi komunitas Desa Kutuh sebagai komunitas yang berada di Kawasan Pantai Pandawa. Pariwisata berbasis komunitas adalah pariwisata yang umumnya berskala kecil dan melibatkan interaksi antara pengunjung dan komunitas tuan rumah, terutama cocok untuk daerah pedesaan dan regional. Community Based Tourism (CBT) umumnya dipahami untuk dikelola dan dimiliki oleh komunitas, untuk komunitas. Ini adalah bentuk pariwisata 'lokal', yang mendukung penyedia dan pemasok layanan lokal dan berfokus pada menafsirkan dan mengkomunikasikan budaya dan lingkungan lokal (Asker, 2010).

Menurut Standar Pariwisata Berbasis Komunitas ASEAN (2016), Pariwisata Berbasis Komunitas adalah suatu bentuk pariwisata yang mengupayakan pemberdayaan masyarakat untuk mengatur pertumbuhan pariwisata dan mencapai keinginan masyarakat terkait dengan kesejahteraannya yang meliputi ekonomi, sosial, dan lingkungan. pembangunan berkelanjutan. Karenanya, konsep itu sendiri tidak hanya melibatkan kemitraan antara bisnis pariwisata dan masyarakat untuk menyerahkan manfaat kepada keduanya, tetapi juga melibatkan komunitas atau penegakan eksternal untuk usaha kecil pariwisata yang pada gilirannya berkomitmen untuk memberikan dukungan untuk proyek komunitas yang meningkatkan kesejahteraan kolektif.

Selain itu, konsep itu sendiri memberdayakan masyarakat lokal untuk menyelesaikan dan mengamankan masa depan sosial ekonomi mereka melalui kegiatan fee-for-services yang biasanya mencakup (1) menghadirkan dan merayakan 
tradisi dan gaya hidup lokal, (2) menjaga sumber daya alam dan budaya, (3) memupuk interaksi tuan rumah-tamu yang adil dan bermanfaat bersama.

Kerangka berpikir dari penelitian ini adalah sebagai berikut:

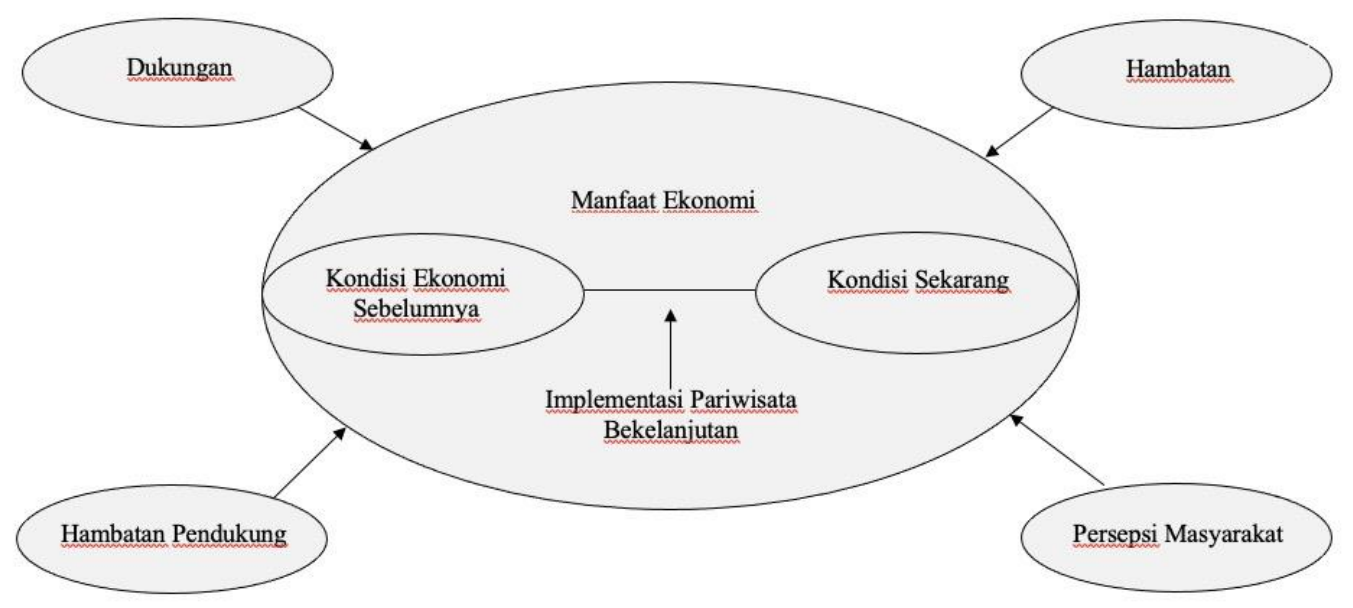

Gambar 2. Kerangka Berpikir

Merujuk kepada kerangka berpikir di atas, peneliti ingin mengetahui apakah implementasi pariwisata berkelanjutan dapat mempengaruhi manfaat ekonomi desa. Oleh sebab itu, penulis melakukan penelitian tentang kondisi ekonomi sebelum dan sesudah implementasi pariwisata berkelanjutan yaitu memastikan kemungkinan mengalami manfaat ekonomi setelah implementasi pariwisata berkelanjutan. Selain itu faktor-faktor yang dapat mempengaruhi implementasi pariwisata berkelanjutan meliputi dukungan, hambatan, hambatan pendukung dan persepsi masyarakat juga dieksplorasi.

Dukungan tersebut dapat diperoleh dari para pemangku kepentingan seperti pemerintah, organisasi lingkungan dan korporasi dalam bentuk uang, pembangunan infrastruktur, dan edukasi tentang pariwisata berkelanjutan kepada warga sekitar.

Hambatan pendukung terletak pada kesadaran warga sekitar tentang konsep pariwisata berkelanjutan dan seberapa mendukung pemerintah daerah terhadap 
penyelenggaraan pariwisata berkelanjutan. Apalagi program penerapan konsep pariwisata berkelanjutan oleh pemerintah daerah masih kurang.

Hambatan merupakan hal yang menghambat pelaksanaan pariwisata berkelanjutan yang bisa berasal dari warga sekitar sendiri yang menentang konsep pariwisata berkelanjutan, pemerintah daerah yang kurang mendukung gagasan pariwisata berkelanjutan atau mungkin kurangnya kemampuan dalam menerapkan pariwisata berkelanjutan, baik dari warga sekitar maupun pemerintah seperti kurang memberikan pelayanan yang memuaskan terhadap wisatawan.

Persepsi masyarakat berfokus pada bagaimana penduduk lokal memandang pariwisata berkelanjutan yang mempengaruhi manfaat ekonomi masyarakat mereka.

\section{Metode}

Dalam penelitian ini, data primer dikumpulkan dengan melakukan wawancara dan kuesioner. Selanjutnya berbagai bukti pendukung didapatkan melalui arsip, wawancara, dan artefak fisik yang akan disajikan dalam bentuk foto. Wawancara akan menjadi salah satu metode pengumpulan data karena dalam penelitian ini dibutuhkan tenaga ahli untuk memberikan informasi yang berguna kepada peneliti yang pada akhirnya dapat menghasilkan hasil yang lebih valid. Adapun pihak yang diwawancara adalah Kepala Desa Kutuh, Kepala Desa Adat atau Desa Adat, dan pengelola Pengelolaan Pantai Pandawa. 


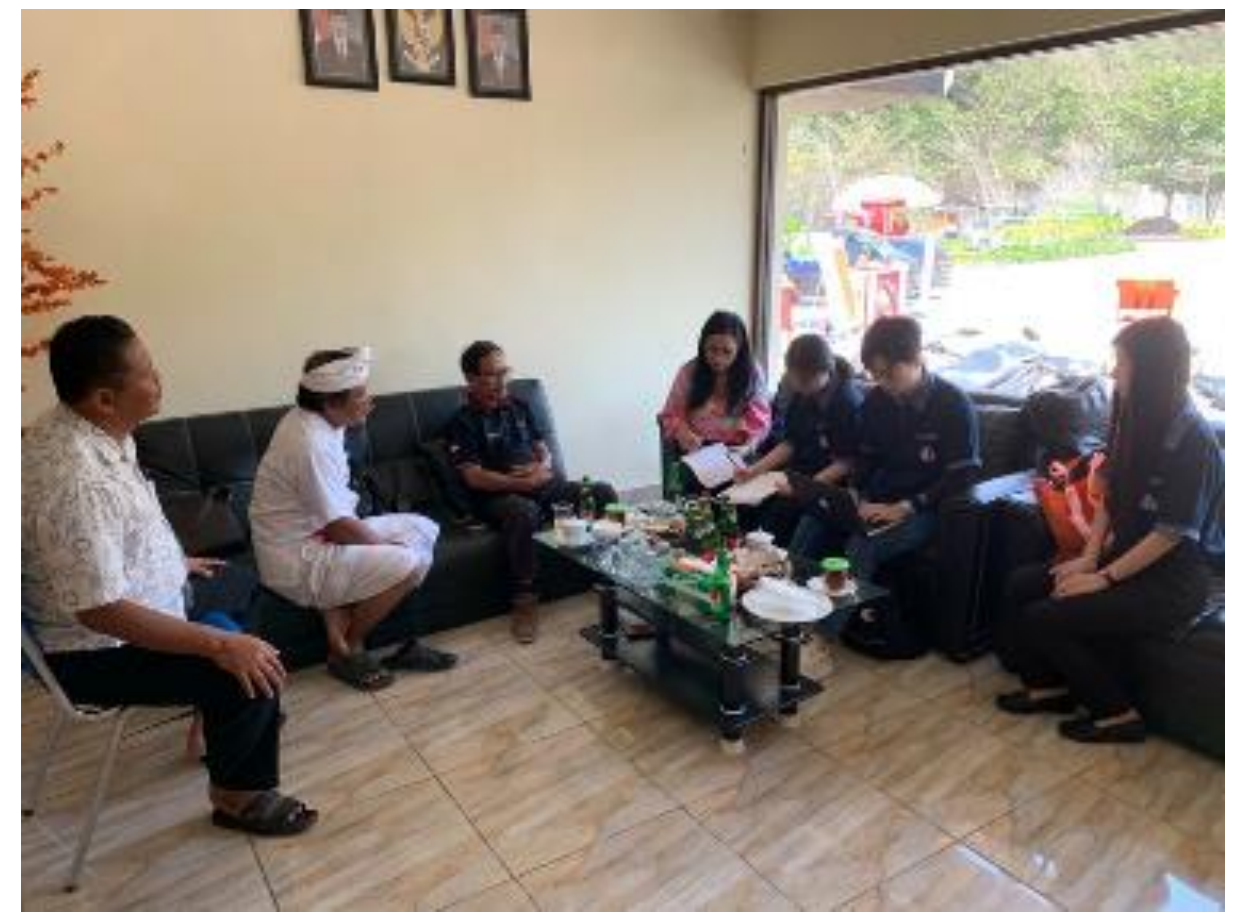

Gambar 3. Wawancara dengan Pengelola Kawasan Pantai Pandawa Sumber: Dokumentasi Peneliti

Pengumpulan data primer lainnya adalah melalui kuesioner. Isi kuesioner adalah profil responden, persepsi masyarakat terhadap pariwisata berkelanjutan dan kriteria manfaat ekonomi dari Global Sustainable Tourism Council (GSTC). Adapun sampel dalam penelitian ini adalah masyarakat sekitar yang tinggal di wilayah pesisir Pantai Pandawa namun tidak semua masyarakat Pandawa diikutsertakan dalam sampel. Sebelum menentukan sampel, kami memisahkan populasi Pantai Pandawa dan memilih hanya kepala keluarga yang dapat merupakan bapak atau ibu sebagai sampel penelitian. 


\section{Hasil dan Pembahasan}

\section{Kondisi Ekonomi Masyarakat Desa Kutuh Sebelum pariwisata berkelanjutan Diimplementasikan di Kawasan Pantai Pandawa}

Sebelum diberlakukannya pariwisata berkelanjutan, kondisi perekonomian masyarakat di Desa Kutuh masih jauh dari kondisi saat ini. Komunitasnya sangat miskin. Sebelum tahun 1997, masih belum ada akses ke Pantai Pandawa. Sebagian besar tempat itu masih tertutup tebing. Saat itu, jalan tersebut belum dibangun. Oleh karena itu, sebagian besar masyarakat yang tinggal di daerah itu harus memanjat tebing sambil membawa rumput laut hasil panen yang sebagian besar merupakan mata pencaharian utama mereka.

Sebelum Pantai Pandawa menjadi destinasi wisata, setiap kepala keluarga di Desa Kutuh harus merogoh kocek kurang lebih 2-4 juta Rupiah untuk kegiatan ritual upacara adat mereka. Sebagian besar masyarakat masih dalam kemiskinan. Mereka jarang makan nasi karena sulit didapat. Oleh sebab itu masyarakat makan ubi jalar sebagai makanan pokok sehari-hari. Mereka memanen ubi jalar sendiri dan bergantung pada musim hujan yang tidak cukup untuk konsumsi setahun. Ketersesiaan air sangat langka karena hanya ada satu sumur dan untuk menuju ke sana. Orang-orang harus mendaki tebing karena tidak ada jalan dan medannya keras. Air yang sangat langka membuat orang mandi seminggu sekali.

\section{Kondisi Ekonomis setelah implementasi pariwisata berkelanjutan}

Setelah diterapkan pariwisata berkelanjutan, kondisi ekonomi di Desa Kutuh semakin membaik. Wisata berkelanjutan mulai diimplementasikan saat Pantai Pandawa diluncurkan pada 27 Desember 2011. Dampaknya bagi masyarakat Desa Kutuh sangat besar. Kepala keluarga tidak perlu mengeluarkan uang untuk kegiatan 
upacara adat. Ada kontribusi untuk kematian pemakaman yang berasal dari CSR desa. Pekerjaan baru diciptakan untuk penduduk lokal.

Saat ini terdapat 70 orang yang bekerja di pengelolaan Pantai Pandawa yang tingkat pendidikannya bervariasi dari SD hingga S2. Sebagian besar masyarakat menjadi pengusaha yang memiliki toko, restoran, dan jasa persewaan. Peluang ini diberikan dari manajemen Pantai Pandawa. Penghasilan masyarakat semakin baik. Apalagi desa tersebut telah memenangkan persaingan desa terpadu tingkat nasional. Meraih peringkat pertama tingkat nasional dan peringkat kedua tingkat regional Jawa. Saat ini desa tersebut juga sudah bebas dari kategori kemiskinan. Meski masyarakat saat ini sudah terbebas dari kemiskinan, gaya hidup mereka tidak banyak berubah. Mereka tetap bertekad untuk hidup sesuai tradisi mereka. Salah satu contohnya adalah tentang apa yang mereka kenakan. Saat para wisatawan berenang, kebanyakan mereka tidak menggunakan pakaian renang yang menutupi sebagian besar tubuhnya seperti mengenakan bikini. Namun masyarakat setempat tidak terpengaruh oleh hal itu. Mereka masih memakai sesuatu yang lebih pantas. Wisatawan dapat mengenakan apa saja yang mereka inginkan tetapi orang Bali tidak ingin terpengaruh.

Perbedaannya adalah ketika mereka dalam kemiskinan, mereka tidak dapat memiliki mobil atau bahkan sekedar sepeda motor. Saat ini, kebanyakan orang memiliki sepeda motor untuk transportasi bahkan ada yang memiliki mobil.

Perusahaan daerah air minum dari Bali Utara ada setelah 1997 karena pengembangan pariwisata. Hal ini menunjukkan bahwa pengembangan pariwisata sangat membantu masyarakat di Desa Kutuh. Dengan keberadaan perusahaan daerah yang memasok air, warga Desa Kutuh tidak perlu lagi mendaki tebing untuk mengambil air dari sumur. Pada era 90-an kehidupan di Desa Kutuh memang mengalami beberapa perubahan. Sebelum Pantai Pandawa dibangun, ada beberapa 
daerah tetangga yang mengalami perkembangan seperti Nusa Dua. Ada beberapa orang dari Desa Kutuh yang berangkat ke Nusa Dua untuk ikut membangun pembangunan sebagai buruh. Dari sana, mereka bisa mendapatkan uang untuk membeli beras. Hal ini menunjukkan bahwa mengembangkan pariwisata di suatu daerah hanya akan mempengaruhi daerah tersebut tetapi juga mempengaruhi daerah sekitarnya untuk mendapatkan dampak yang positif.

\section{Hambatan dalam implementasi pariwisata berkelanjutan dari sisi manfaat ekonomi}

Hambatan terbesar dalam meningkatkan manfaat ekonomi adalah mengubah paradigma warga setempat dan menangani rakyatnya sendiri. Menurut pendapat manajer, jauh lebih mudah mengelola orang luar yang mencoba bertahan hidup dibandingkan dengan orangnya sendiri. Penduduk setempat memiliki dasar atau prinsip tentang "bisnis dan tempat ini milik saya" yang membuat mereka keras kepala.

Oleh karena itu, manajer memberikan solusi dengan menjelaskan dan memberi mereka pengertian. Pada awalnya perjuangan mengelola rakyatnya sendiri itu berat. Misalnya jika manajemen memberikan pemecatan kepada orang-orangnya sendiri, itu menjadi masalah karena mereka melakukannya kepada orang-orangnya sendiri. Berbeda jika terjadi pada orang luar. Itulah sebabnya manajer berusaha memberikan pengertian untuk kepentingan rakyatnya sendiri. Meski sempat ada kasus di mana manajemen memecat salah satu stafnya yang merupakan warga setempat, hal ini harus dilakukan agar Pantai Pandawa bisa berkembang lebih baik.

Ada kasus dimana tamu datang namun masyarakat sekitar kurang melayani maka tamu tersebut memberikan keluhan. Oleh sebab itu pihak pengelola memberikan pengertian bahwa para tamu yang datang ke Pantai Pandawa untuk berlibur melayani mereka dengan ikhlas dan saat ini hasilnya semakin baik. Di masa 
lalu sebelum Pantai Pandawa diresmikan, pengunjungnya hanya masyarakat sekitar. Mereka melayani tamu dengan cara yang menurut mereka nyaman bagi mereka dan tidak memastikan apakah tamu itu senang atau tidak. Tapi sekarang tamunya bisa turis lokal atau bahkan mancanegara maka pelayanannya harus memenuhi standar seperti kebersihan, kesopanan, dan lain sebagainya. Sebelumnya, sebagian besar masyarakat hanya melayani rumput laut sebagai mata pencaharian utama sehingga tidak mengalami kendala apapun. Namun, setelah mereka mulai berurusan dengan para pelancong, mereka menghadapi banyak kendala. Konflik belum terjadi sampai sekarang.

\section{Profil Responden}

Total ada 90 responden. Untuk jenis kelamin, $66 \%$ responden berjenis kelamin laki-laki dengan jumlah 59 responden dan 34\% berjenis kelamin perempuan dengan total 31 responden.

Untuk umur, didapatkan dari umur 17-20 tahun ada 13\% dengan jumlah 12 responden, umur 21-30 tahun ada 26\% dengan jumlah 23 responden, umur 31-40 tahun adalah 22\% diantaranya dengan total 20 responden, usia 41-50 tahun sebanyak $29 \%$ dengan total 26 responden, usia 51-60 tahun sebanyak 9\% dengan jumlah total 8 responden, dan terakhir namun tidak kalah pentingnya. usia diatas 61 tahun sebanyak $1 \%$ dengan total 1 responden.

Untuk bidang pendidikan, terdapat responden yang lulus dari beberapa gelar. Untuk tingkat SD ada 13\% dengan jumlah 12 responden, SMP 22\% dengan jumlah 20 responden, SMA 40\% dengan total 36 responden, diploma 1-3 ada 17\% diantaranya dengan total 15 responden, sarjana 1 atau diploma 4 6\% diantaranya dengan total 5 responden, dan terakhir ada $2 \%$ dari gelar lain yang tidak ditentukan dengan a total 2 responden. 
Untuk pekerjaan, $61 \%$ diantaranya adalah pegawai atau pekerja tetap dengan jumlah 54 responden, 5\% diantaranya adalah ibu rumah tangga dengan jumlah 4 responden, 10\% diantaranya adalah pekerja lepas dengan jumlah 9 responden, 18\% dari mereka adalah pengusaha dengan total 16 orang responden, dan terakhir namun tidak sedikit ada $6 \%$ dari mereka dengan pekerjaan lain yang tidak ditentukan dengan total 5 responden.

Untuk jenis mata pencaharian, 1\% di antaranya dari aparatur sipil negara dengan jumlah 1 responden, 66\% di antaranya dari perdagangan dengan total 55 responden, 2\% di antaranya dari pertanian / perkebunan dengan total 2 responden, dan terakhir ada 31\% di antaranya dari sektor lain yang tidak ditentukan dengan total 26 responden.

Untuk pendapatan per bulan terdapat 62\% diantaranya berpenghasilan dibawah $\operatorname{Rp} 2.700 .000$ dengan total 56 responden, 36\% diantaranya berpenghasilan antara Rp 2.700.001-6.000.000 dengan total 32 responden, dan terakhir tetapi tidak sedikit ada 2\% diantaranya dengan penghasilan antara Rp 6.000.001-11.000.000 dengan jumlah responden sebanyak 2 orang. Tidak ada yang berpenghasilan di atas Rp 11.000.000.

Untuk pengetahuan tentang pariwisata berkelanjutan sebanyak $77 \%$ diantaranya mengetahui tentang pariwisata berkelanjutan dengan jumlah 69 responden dan 23\% diantaranya tidak mengetahui tentang pariwisata berkelanjutan dengan jumlah 21 responden.

Bagi masyarakat yang mengetahui tentang pariwisata berkelanjutan, $18 \%$ di antaranya mengetahuinya dari masyarakat dengan total 14 responden, 1\% di antaranya mengetahuinya dari keluarga dengan jumlah 1 responden, 25\% di antaranya mengetahuinya dari teman dengan total 20 responden, 19\% diantaranya mengetahuinya dari pemerintah dengan total 15 responden, $4 \%$ di antaranya 
mengetahuinya dari perguruan tinggi dengan total 3 responden, 4\% mengetahuinya dari sekolah dengan total 3 responden $14 \%$ tahu dari website dengan total 11 responden, dan terakhir 15\% diantaranya mengetahuinya dari sumber lain yang tidak ditentukan dengan total 12 responden.

\section{Persepsi masyarakat terhadap pariwisata berkelanjutan dari aspek ekonomi}

Aspek ekonomi meliputi 7 pernyataan. Karena pariwisata memegang peranan penting dalam pembangunan ekonomi daerah, sebagian besar responden memilih sangat setuju dengan persentase $72,2 \%$ dan sebanyak 65 orang. Paling sedikit responden memilih tidak setuju dan sedikit tidak setuju dengan persentase $2,2 \%$ dan sebanyak 2 orang. Ada 11.1\% responden dengan total 10 orang yang memilih sangat tidak setuju.

Untuk pariwisata meningkatkan taraf hidup masyarakat, sebagian besar responden memilih sangat setuju dengan persentase $66,7 \%$ dan total 60 orang. Paling sedikit responden memilih tidak setuju dan sedikit tidak setuju dengan persentase $4,4 \%$ dan total 4 orang. Ada $10 \%$ responden dengan total 9 orang yang memilih sangat tidak setuju.

Terkait butir bahwa pariwisata meningkatkan penerimaan pajak suatu masyarakat, sebagian besar responden memilih sangat setuju dengan persentase $53,3 \%$ dan total 48 orang. Responden paling sedikit memilih tidak setuju dengan persentase $4.4 \%$ dan total 4 orang. Ada 10\% responden dengan total 9 orang yang memilih sangat tidak setuju.

Sementara untuk aspek bahwa pariwisata menciptakan lapangan kerja baru bagi responden lokal, sebagian besar responden memilih sangat setuju dengan persentase $74,4 \%$ dan total 67 orang. Tidak ada responden yang memilih sedikit tidak setuju. Ada 14,4\% responden dengan total 13 orang yang memilih sangat tidak setuju. 
Terkait keragaman pariwisata ekonomi pedesaan, sebagian besar responden memilih sangat setuju dengan persentase 58,9\% dan sebanyak 53 orang. Paling sedikit responden memilih tidak setuju dengan persentase 3,3\% dan sebanyak 3 orang. Ada $12,2 \%$ responden dengan total 11 orang yang memilih sangat tidak setuju.

Sedangkan untuk pariwisata menghasilkan peningkatan biaya hidup, sebagian besar responden memilih sangat setuju dengan persentase 60\% dan total 54 orang. Paling sedikit responden memilih tidak setuju dengan persentase 3,3\% dan sebanyak 3 orang. Ada 10\% responden dengan total 9 orang yang memilih sangat tidak setuju.

Akhirnya terkait pendapatan dari kegiatan pajak pariwisata harus diinvestasikan dalam pengembangan pariwisata kedepannya, sebagian besar responden memilih sangat setuju dengan persentase $60 \%$ dan total 54 orang. Paling sedikit responden memilih tidak setuju dengan persentase 1,1\% dan total 1 orang. Responden sebanyak $13,3 \%$ dengan total 12 orang yang memilih setuju dan sangat tidak setuju.

\section{Keberlanjutan dalam manfaat ekonomi bagi masyarakat yang diadaptasi dari} Global Sustainable Tourism Council

Pada bagian ini dijelaskan hasil dari manfaat ekonomi bagi masyarakat. Aspekaspek yang dilihat terdiri atas:

1. Hukum atau Kebijakan yang Mendukung Kesempatan Kerja yang Setara untuk Semua Orang

Terdapat $42,2 \%$ responden yang setuju dengan total 38 responden untuk undang-undang atau kebijakan yang mendukung kesempatan kerja yang setara bagi semua orang, termasuk perempuan, pemuda, penyandang disabilitas, minoritas dan kelompok rentan lainnya, dan 18,9\% responden yang tidak setuju. dengan jumlah 17 
responden sedangkan sebanyak 38.9\% responden tidak mengetahuinya dengan total 35 responden.

2. Program Pelatihan yang Memberikan Akses Setara kepada Semua

Ada 54,4\% responden yang setuju dengan total 49 responden untuk program pelatihan yang memberikan akses yang sama kepada semua yang juga mencakup perempuan, pemuda, penyandang disabilitas, minoritas dan kelompok rentan lainnya, dan 13,3\% responden yang tidak setuju dengan a Sebanyak 12 responden sedangkan ada 32,2\% responden tidak mengetahuinya dengan total 29 responden.

3. Hukum atau Kebijakan yang Mendukung Keselamatan Kerja yang Setara untuk Semua Orang

Terdapat $82,2 \%$ responden yang setuju dengan total 74 responden untuk Undang-undang atau kebijakan yang mendukung keselamatan kerja bagi semua, dan $10 \%$ responden yang tidak setuju dengan total 9 responden, sedangkan ada 7,8\% responden setuju. Tidak mengetahui dengan total 7 responden.

4. Hukum atau Kebijakan yang Mendukung Upah yang Adil untuk Semua

Ada 53,3\% responden yang setuju dengan total 48 responden untuk undangundang atau kebijakan yang mendukung upah yang adil bagi semua termasuk perempuan, pemuda, penyandang disabilitas, minoritas dan kelompok rentan lainnya, dan 17,8\% dari responden yang tidak setuju dengan total Dari 16 responden sedangkan terdapat $28,9 \%$ responden tidak mengetahuinya dengan total 26 orang.

5. Program yang mendukung dan membangun kapasitas perusahaan lokal kecil dan menengah

There are $72.2 \%$ of the respondents who agree with a total of 65 respondents for programs to support and build the capacity of small and medium sized local companies, and $13.3 \%$ of the respondents who disagree with a total of 12 respondents, 
while there are $14.4 \%$ of the respondents do not know about it with a total of 13 respondents.

6. Program yang Mendorong Perusahaan untuk membeli Barang dan Jasa Buatan Lokal

Terdapat $67,8 \%$ responden yang setuju dengan total 61 responden untuk Program yang mendorong perusahaan untuk membeli barang dan jasa buatan dalam negeri, dan 14,4\% responden yang tidak setuju dengan total 13 responden, sedangkan ada $17,8 \%$ responden tidak mengetahuinya dengan total 16 responden.

7. Program Pembinaan dan Pengembangan Produk Lokal Berkelanjutan Berbasis Alam dan Budaya Lokal

Terdapat $66,7 \%$ responden yang setuju dengan total 60 responden untuk Program yang mempromosikan dan mengembangkan produk lokal berkelanjutan berbasis alam dan budaya lokal, dan $12,2 \%$ responden yang tidak setuju dengan total 11 responden, sedangkan ada Sebanyak 21,1\% responden tidak mengetahuinya dengan jumlah 19 responden.

8. Program untuk Melibatkan Pengrajin Lokal, Petani, dan Pemasok dalam Rantai Nilai Pariwisata

Terdapat $62,2 \%$ responden yang setuju dengan total 56 responden untuk pengumpulan publik tahunan dan pelaporan data pekerjaan terkait pariwisata yang diurutkan berdasarkan jenis kelamin dan kelompok umur, dan 14,4\% dari responden yang tidak setuju dengan total 13 Responden sedangkan terdapat 23,3\% responden yang tidak mengetahuinya dengan total 21 responden. 
9. Puas dengan Kesejahteraan Ekonomi Masyarakat Lokal Saat Ini

Terdapat $80 \%$ responden yang merasa puas dengan total 72 responden terhadap kesejahteraan ekonomi masyarakat setempat saat ini, sedangkan 20\% responden yang tidak puas dengan total sebanyak 18 responden.

\section{Simpulan dan Saran}

\section{Simpulan}

Terdapat dua evaluasi yang akan disimpulkan. Pertama adalah persepsi utama dari pemerintah daerah. Dari wawancara yang telah dilakukan, penulis dapat menyimpulkan bahwa pariwisata berkelanjutan memang membawa dampak positif terhadap kondisi perekonomian di Desa Kutuh. Sebelum pariwisata berkelanjutan diterapkan, masyarakatnya sangat miskin. Konsumsi dari panen sendiri hampir tidak mencukupi kebutuhan mereka. Apalagi warga sekitar jarang mandi karena hanya bisa mandi seminggu sekali. Setelah diterapkan pariwisata berkelanjutan, desa tersebut berhasil memenangkan persaingan desa terpadu di tingkat nasional. Meraih peringkat pertama tingkat nasional dan peringkat kedua tingkat regional Jawa. Saat ini desa tersebut sudah bebas dari kategori kemiskinan.

Kedua, persepsi utama dari warga sekitar. Ada 4 aspek yang dihimpun dari masyarakat sekitar yaitu lingkungan, ekonomi, sosial budaya, dan infrastruktur, namun pada tulisan ini lebih difokuskan pada aspek ekonomi. Dari aspek ekonomi, penulis dapat menyimpulkan bahwa pariwisata memberikan manfaat ekonomi bagi masyarakat di Desa Kutuh. Ada beberapa pernyataan untuk aspek ekonomi. Semua pernyataan tersebut menunjukkan bahwa masyarakat lokal di Desa Kutuh setuju bahwa pariwisata membawa manfaat ekonomi bagi masyarakatnya. 
Saran

Capaian-capaian dari Desa Kutuh saat ini tidak terlepas dari Kerjasama komunitas masyarakat yang memberikan dampak luar biasa bagi perekonomian desa ini. Oleh sebab itu, capaian ini harus dipertahankan, juga agar permalahan ekonomi tidak menjadi sumber perpecahan pada masyarakat desa. Sangat penting bagi Desa Kutuh untuk fokus juga pada aspek tata kelola destinasi, keberlanjutan budaya dan keberlanjutan lingkungan.

\section{Ucapan Terima Kasih}

Terimakasih kami yang utama kami persembahkan kepada Tuhan Yang Maha Esa, atas izinNya lah maka kami dapat menyelesaikan penelitian ini. Terimakasih juga kami ucapkan kepada para pengelola Kawasan Pantai Pandawa atas kesediaannya untuk berbagi pengalaman dan mendukung kami dalam hal data. Semoga melalui tulisan ini, akan semakin banyak destinasi yang terinspirasi untuk menerapkan pariwisata berkelanjutan.

\section{Daftar Pustaka}

Asker, S., Boronyak, L., Carrard, N., \& Paddon, M. (June, 2010). Effective communitybased tourism: a best practice manual, p. 2. Sustainable Tourism Cooperative Research Centre, Gold Coast. Australia.

Dharmayudha, I. M. S. (2001). Desa adat: Kesatuan masyarakat hukum adat di Propinsi Bali. Denpasar, Bali: Upada Sastra, p.18.

GSTC (2013). Global Sustainable Tourism Council Criteria and Suggested Performance Indicators for Destinations, version 1, p.2-6. Travel Forever: Global Sustainable Tourism Council, 2013. 
Kostić, M. and Jovanović-Tončev, M. (2014). Importance of sustainable tourism: Sustainable development and tourism. Sinteza, January 2014, p.723.

Ramdhani G. (02 December, 2018). Kemenpar Umumkan 17 Peraih Indonesia Sustainable Tourism Award 2018.

Swabawa, A. A. P., Pemayun, I D. G. A., \& Sagitarini, L. L. (2018). Analysis of Creative Product Potentials of Pandawa Beach, Kutuh Village, Bali, p.114. SOSHUM: Jurnal Sosial dan Humaniora [Journal of Social Sciences and Humanities], [S.l.], v. 8, n. 2, p. 113 - 122, August.2018.

The ASEAN Secretariat Jakarta (2016). ASEAN Community-Based Tourism Standard, p.1-2. Jakarta: ASEAN Secretariat, January 2016.

The Bali Today.com

UNEP and UNWTO (2005). Making Tourism More Sustainable - A Guide for Policy Makers. UNEP: Paris, France; WTO: Madrid, Spain, 2005, p.9, 20.

\section{Profil Penulis}

Dr. Diena Mutiara Lemy, A.Par., M.M. adalah Dekan Fakultas Pariwisata Universitas Pelita Harapan. Ketika berkunjung sebagai juri dalam Indonesia Sustainable Tourism Award (ISTA) 2018, ia sangat terkesan dengan tata kelola Kawasan pantai Pandawa yang dilakukan oleh komunitas namun sangat maju. Oleh sebab itu, dia mengajak beberapa mahasiswa untuk melakukan penelitian bersama terkait dampak ekonomi sebagai hasil tata kelola pariwisata berkelanjutan.

Kim Min Jun, S.Tr.Par. adalah lulusan Program Studi Pengelolaan Perhotelan Universitas Pelita Harapan. Ia menyelesaikan studinya pada awal tahun 2020.

Madeline Stefanie Tjang, S.Tr.Par. adalah lulusan Program Studi Pengelolaan Perhotelan Universitas Pelita Harapan. Ia menyelesaikan studinya pada awal tahun 2020.

Wu Lei Lei, S.Tr.Par. adalah lulusan Program Studi Pengelolaan Perhotelan Universitas Pelita Harapan. Ia menyelesaikan studinya pada awal tahun 2020. 